$\begin{gathered}\text { Journal of Business Management and } \\ \text { Economic Research }\end{gathered}$
2019, 3(11): 1-7 DOI: 10.29226/TR1001.2018.97
Journal Homepage: https://www.jobmer.org

\title{
The Role of Employees with the Investment Capital of The Enterprises in Industrial Parks: Research in Thai Nguyen Province
}

\author{
Le Thi Yen \\ Thai Nguyen University of Economics and Business Administration, Vietnam, \\ ltyen@tueba.edu.vn
}

Pham Minh Hoa

The ministry of Finance, Vietnam

\begin{abstract}
Industrial parks are formed and developed in countries in general and in localities in particular as an effective channel to attract investment capital, thereby promoting growth and economic development of local as well as each country. One of the key tasks of these industrial parks is to attract investment flows not only from domestic enterprises and foreign enterprises. One of the factors that have a major influence on attracting investment capital of enterprises that are labor including the quantity and quality of labor in industrial parks. Based on the analysis of the real situation of labor in industrial zones in Thai Nguyen province as well as analyzing the requirements of enterprises with local labor resources, especially in the context of international economic integration as at present, the research will also propose a number of recommendations for good local addressing labor problems, thereby helping to attract investment capital of enterprises in the local industrial parks.
\end{abstract}

Keywords: Industrial zone, labor, capital attraction, investment, Thai Nguyen province

\section{Introduction}

With the general trend of the country, Thai Nguyen province has advocated to build and synchronize industrial parks in the overall planning of economic development - society of the country, by the end of 2017, Thai Nguyen province has six industrial zones: Song Cong 1, Song Cong 2, Nam Pho Yen, Tay Pho Yen, Quyet Thang, Diem Thuy.The industrial park establishment and development have contributed to restructuring the economy, creating jobs for thousands of workers, development of ancillary industries and services in the province. As of the end of 2017, had accumulated 182 projects have been certified investment in industrial zones of the province with a total registered capital of about 7.061 billion US dollars of investment and approximately 14192.72 billion; Total investment capital is about USD 6.4 billion and VND 7540.3 billion (Thai Nguyen Industrial Park Management Board, 2018). In addition, by the end of 2017, Of the total of 182 projects licensed for investment in industrial 
zones in Thai Nguyen province has 113 projects in operation, which 21 new projects in operation, the consumption in 2017 sales reached about 28.1 billion estimate and 5355.8 billion.

Although the investment in Thai Nguyen's industrial zones tends to increase, especially from foreign invested enterprises (typically Samsung) however, it is still limited, not corresponding with the available potential of the local, so the research of activities to attract investment in industrial parks, identifying the factors that influence the attraction of investment in industrial zones is essential. Based on that, the author proposes some measures to enhance investment attraction in industrial zones in province in the future.

Within the scope of this research, the article focused on the labor factor affecting attract investment in industrial zones.Facts and inheritance of previous studies show that labor source is one of the factors that have a great influence on attracting investment capital of enterprises into industrial zones. This study will look at enterprises' perceptions of labor, their satisfaction with quality and local labor resources, from this; it is possible to identify some of the investment decisions of these enterprises for industrial zones.

\section{Overview of research}

In the world, the industrial park model is formed as an effective channel for attracting investment capital, contributing to the socio-economic development of the country. Issues related to industrial parks have received the attention of researchers and policy makers. Some studies have been done to assess the impact of the industrial zone to the socio - economic development of countries such as research Damborsky et al (2013), Benacek V (1999), Blomstrom et al (1998), Kim et al (1997) these studies have shown both the direct and indirect impact of foreign direct investment enterprises (These enterprises operating in the industrial park) to the socio-economic development. Simultaneously, the researches also make policy recommendations to promote the attraction of foreign direct investment in the industrial zone in particular and the country in general. Some other researchers around the world are concentrated in the direction of how to develop the industrial zone in the direction of the green industrial research: Popescu et al (2008), Lambert et al (2002).

A number of studies have been carried out in Viet Nam in different directions, in particular some of them have been carried out in the direction of attracting investment capital for the development of infrastructure in industrial zones such as Vu Dai Thang (2012), Ngoc Hoa (2012), Tran Van Hau (2011), ... These studies analyze the situation and propose a number of measures to develop industrial parks, export processing zones and economic zones. The research methodology used in these studies is the descriptive statistics and SWOT matrix application that identifies the strengths, weaknesses, opportunities and challenges of attracting investment capital to develop the industry zones. Some studies have focused consideration to the location of workers to industrial areas, despite recognizing the location of the labor force, though, authors do not consider the impact of labor to attract investment in industrial areas such as research of the author Thanh Tung.

\section{Research methodology}

The data used in the research were collected from two sources:

Firstly, the secondary data was collected from the Annual Review Report of the Management Board of Thai Nguyen Industrial Parks. This data was collected to analyze the situation of attracting investment capital of enterprises to industrial parks in Thai Nguyen province. Second, the primary data source: This data was collected from the survey data of enterprises in Thai Nguyen province: Including those who invested in industrial parks and those who did not invest in industrial zones. Second, the primary data source: This data was collected from the 
survey data of enterprises in Thai Nguyen province: Including those who invested in industrial parks and those who did not invest in industrial parks. This data was collected to help the author assess the subjective decision to invest in industrial parks on the current practice of labor in industrial parks in the province. With the data collected, the researchers used statistical methods descriptive and comparative analysis to perform analysis in the article.

\section{Research Findings}

\subsection{Results of attracting investment capital of enterprises in industrial parks in Thai Nguyen province}

In the period from 2015 to 2017, the number of registered projects in Thai Nguyen's industrial parks tends to increase slightly over the years, however this increase is not much, and the investment projects in the industrial parks are mainly focused on Diem Thuy IPs and Song Cong I IPs.

Table 1: Results of attracting investment capital for new production and business in industrial zones in Thai Nguyen province

\begin{tabular}{|c|c|c|c|c|c|c|c|c|c|c|c|c|c|}
\hline \multirow[b]{3}{*}{ TT } & \multirow[b]{3}{*}{$\begin{array}{c}\text { Tên } \\
\text { KCN }\end{array}$} & \multicolumn{4}{|c|}{2015} & \multicolumn{4}{|c|}{2016} & \multicolumn{4}{|c|}{2017} \\
\hline & & \multicolumn{2}{|c|}{ FDIProject } & \multicolumn{2}{|c|}{ DDI Project } & \multicolumn{2}{|c|}{ FDIProject } & \multicolumn{2}{|c|}{ DDIProject } & \multicolumn{2}{|c|}{ FDIProject } & \multicolumn{2}{|c|}{ DDI Project } \\
\hline & & $\begin{array}{c}\text { Number } \\
\text { of new } \\
\text { projects }\end{array}$ & $\begin{array}{c}\text { Total } \\
\text { investment } \\
\text { (million } \\
\text { USD) }\end{array}$ & $\begin{array}{c}\text { Number } \\
\text { of new } \\
\text { projects }\end{array}$ & $\begin{array}{c}\text { Total } \\
\text { investment } \\
\text { capital } \\
\text { (billion } \\
\text { dong) } \\
\end{array}$ & $\begin{array}{c}\text { Number } \\
\text { of new } \\
\text { projects }\end{array}$ & $\begin{array}{c}\text { Total } \\
\text { investment } \\
\text { (million } \\
\text { USD) }\end{array}$ & $\begin{array}{c}\text { Number } \\
\text { of new } \\
\text { projects }\end{array}$ & \begin{tabular}{|} 
Total \\
investment \\
capital \\
(billion \\
dong)
\end{tabular} & $\begin{array}{c}\text { Number } \\
\text { of new } \\
\text { projects }\end{array}$ & $\begin{array}{c}\text { Total } \\
\text { investment } \\
\text { (million } \\
\text { USD) }\end{array}$ & $\begin{array}{c}\text { Number } \\
\text { of new } \\
\text { projects }\end{array}$ & $\begin{array}{c}\text { Total } \\
\text { investment } \\
\text { capital } \\
\text { (billion } \\
\text { dong) }\end{array}$ \\
\hline 1 & $\begin{array}{l}\text { Diem } \\
\text { Thuy } \\
\text { IPs }\end{array}$ & \multirow{2}{*}{18} & \multirow{2}{*}{171,55} & \multirow{2}{*}{4} & \multirow{2}{*}{477,04} & 18 & 122,86 & 3 & 617,69 & 9 & 17,39 & 6 & 459,528 \\
\hline 2 & $\begin{array}{l}\text { Song } \\
\text { Cong I } \\
\text { IPs }\end{array}$ & & & & & 3 & 2,03 & 2 & 42,09 & 2 & 0,48 & 2 & 94 \\
\hline 3 & $\begin{array}{l}\text { Yen } \\
\text { Binh } \\
\text { IPs }\end{array}$ & - & - & - & - & 1 & 5,3 & 2 & 359,6 & - & - & 1 & 925 \\
\hline 4 & $\begin{array}{l}\text { Nam } \\
\text { Pho } \\
\text { Yen } \\
\text { IPs }\end{array}$ & - & - & - & - & - & - & - & - & - & - & 3 & 122,1 \\
\hline & $\begin{array}{l}\text { tal } \\
\text { ect) }\end{array}$ & & 2 & 2 & & & & 29 & & & & 23 & \\
\hline
\end{tabular}

Source: The Management Board of industrial parks in Thai Nguyen

In 2015, it attracted 22 new investment projects, including 18 FDI projects with a total investment of US \$ 171.55 million and four domestic investment projects (DDI) with the total capital of VND477.04 billion. Specifically, these new investment projects are invested in Diem Thuy Industrial Park and Song Cong I Industrial Park.

In 2016, IZs have attracted 29 new investment projects, including 22 FDI projects and 07 DDI projects with total newly registered capital of USD 126.84 million and VND 1,019.38 billion, of 
which: In 2017, 23 new investment certificates were granted to 11 FDI projects and 12 DDI projects with total registered capital of USD 17.87 million and VND 1,600.628 billion.

According to the data sheet, over the three years of research, in 2016 attracted more investment projects, besides the number of FDI projects was higher than that of DDI projects.

Diem Thuy industrial parks and Song Cong industrial parks I are getting more attention from investors at domesstic and abroad the most, every year there are more FDI and DDI invested in two industrial zone also IPs Nam Pho Yen currently less attracted most investment, through three years of research without any FDI projects invested in this industrial park, the new 20173 DDI projects with a total investment of 122.1 billion.

\subsection{Evaluation of enterprises on the role of labor in attracting investment capital in industrial parks}

The implementation of investment activities in industrial areas of the business have no small impact on employment of local people as well as neighborhood residents. In fact, by the end of 2017, more than 102 thousand workers are working in industrial zones in Thai Nguyen province, as follows:

Table 2: Impact of attracting investment in industrial zones to the work of the people

\begin{tabular}{|c|c|}
\hline Years & The number of jobs in the industrial park \\
\hline Unit & Labor \\
\hline 2014 & 44735 \\
\hline 2015 & 81368 \\
\hline 2016 & 90000 \\
\hline 2017 & 102901 \\
\hline
\end{tabular}

Source: Management Board of Industrial Parks

From the above table, as enterprises invest more and more in industrial zones, the number of jobs is increasing, specifically, from 2014 to 2015, the operation of the company Sam Sung Viet Nam's system in the industrial park in Thai Nguyen province, which has attracted a large number of workers from neighboring localities as well as local workers, the number of jobs created increased twice as many as 2015, the number of jobs created in 2015 is more than 80,000 jobs with more than 80,000 workers working in industrial zones in Thai Nguyen 2016, over 90,000 jobs will be created, increasing 111.11\% over 2015.

In 2017 created new jobs and created jobs for 102,901 workers, increased 16.17\% over the same period, in which some 102257 workers in the country is increasing by $14.98 \%$ compared to 2016, the number of foreign workers is 644 , increased $38.49 \%$ compared to 2016 , female laborers are 75,683 , increasing by $18.61 \%$ compared to 2016 , accounting for $73.55 \%$ of the total labor force in the industrial zone.

Thus, it can be seen that attracting investment capital of enterprises into industrial parks is of great significance in creating jobs for laborers of the local and surrounding areas, thereby contributing to improving the lives of the people, promote the growth and development of the local economy. 
Enterprises are those who directly participate in the investment process. Therefore, the evaluation of enterprises will be a valuable source of information to find out the causes of ineffective problem in attracting investment in industrial zones.

Researchers surveyed 60 enterprises in the province of Thai Nguyen, have knowledge of the industrial park to see their evaluation of labor in the province and the impact of these resources to attract investment to industrial parks in the province.In this study, the author conducted a survey of enterprises in Thai Nguyen province, in which the object of the author's survey of businesses operating in the industrial park in the province of Thai Nguyen and businesses outside the industry.

The purpose of the author examines these two groups of enterprises to give a more multidimensional perspective on the views of each group of enterprises on the impact of labor on the decision to invest in the industrial zones of the enterprise.

To get the answer sheet of the enterprise, the author has to direct the enterprise, among enterprises author's survey authors collected directly questionnaire 26 enterprises, and 34 enterprises selected not meet directly authors have sent the survey via email and receive answers via email. The author uses 5 point Likert scale to measure the rating of the enterprise according to the ascending order from 1 to 5 where 1 is very poor and 5 is very good.

Table 3: Assessment of enterprises on labor in industrial zones in Thai Nguyen province Unit: Enterprise

\begin{tabular}{|l|l|}
\hline Criteria & Review Score \\
\hline 1. Number of employees meet the requirements of enterprises & 3,67 \\
\hline 2. Labor meets requirements for work at enterprises & 3,06 \\
\hline 3. Labor can absorb and use technology & 3,12 \\
\hline 4. Trained professionals & 3,15 \\
\hline 5. Discipline in the work process of labor & 3,21 \\
\hline 6. Foreign language skills, computer skills & 2,95 \\
\hline 7.Labor is trained soft skills & 2,98 \\
\hline
\end{tabular}

Data source: Synthesized from the author's survey

Regarding labor in industrial zones in Thai Nguyen province, it has not met the requirements of enterprises in terms of quality and quantity, some enterprises after the workers on Lunar New Year holiday, they do not return to the IP,

Enterprises do not have enough labor to continue production, in addition, the quality of labor is not good, labors have not been trained properly, and technical workers have not been through basic training.

The results of enterprises' assessment on labor in industrial zones in the province are not high, mainly evaluated at average level. In particular, the ability to communicate in English and computer skills as well as soft skills of labor is not guaranteed to meet the needs of work in the context of international economic integration as today (evaluation point average of 3.0 points out of 5 points). Moreover, today the company Sam Sung operating in industrial parks Yen Binh and has attracted a huge labor, however, workers in the province do not really meet the requirements of enterprises, not to mention the requirements of the Korean language. 
Table 4: Assessment of enterprise satisfaction on labor

\begin{tabular}{|l|l|}
\hline Review of the enterprises & The number of enterprises \\
\hline 1. Very Dissatisfied & 0 \\
\hline 2. Dissatisfied & 17 \\
\hline 3. Normal & 21 \\
\hline 4. Satisfied & 22 \\
\hline 5. Very Satisfied & 0 \\
\hline
\end{tabular}

Source: Synthesized from the author's survey

With the assessment of enterprises in industrial zones, the number of satisfied enterprises is not high, with 22/60 enterprises surveyed answered is satisfied; mainly businesses are confused or dissatisfied with labor in industrial zones in the province of Thai Nguyen. Therefore, it affects relatively large investment decisions of enterprises in industrial zones in Thai Nguyen.

\section{Recommendations}

Labor sources have important implications and decisions leading to the economic and social development. Foreign companies are often not satisfied with the quantity and quality of labor provided to them. Therefore, measures to ensure and enhance the quality of human resources required to meet in order to stimulate investment attraction for IPs should: Continue to propagate and raise awareness about the position and role of human resources in socioeconomic development in general and to meet the demand for investment capital of domestic and foreign enterprises in particular.

Scale up and continue to diversify, socialization in training human resources to rapidly increase the size of trained workforce.

Improve the quality and innovation of content and methods of training of human resources. Training quality requirements of schools to follow the progress of science and technology and the development of technology to meet the human resources required by the foreign company.

Develop a policy system for training, using and attracting human resources.

Diversify forms of training, expand the scale of universities, colleges, secondary and vocational training centers, the training system formed spearhead large-scale high quality.

The province should pay more attention to the vocational training system: from schools, equipment, teachers, training areas, programs and training content.

Each district has at least one vocational training school for young people, when the plan to recover land is to immediately provide vocational training for these schools.

It is necessary to have policies to develop and attract laborers, especially high-level laborers from other places, so as to take initiative in meeting labor demands for industrial parks. 


\section{References}

The Management Board of Thai Nguyen Industrial Parks, (2018), 2017 Review Report and Directions for Operations 2018

Management Board of Industrial Parks of Thai Nguyen Province, (2018), Report on the Operation of Enterprises in Thai Nguyen Industrial Zone

Management Board of industrial Parks in Thai Nguyen province, (2014), Report on overall plan for socio-economic development of Thai Nguyen province up to 2020

Blomstrom et al., (1998), Multinational Corporations and Spillovers, Journal of Economic Surveys Vol. 12, Iss.3, pp. 247-277. ISSN 1467-6419.

Bomstrom et al., (1998), Technology Transfer and Spillovers: Does Local Participation with Multinationals Matter? NBER Working Paper Series No 6816.

Damborsky et al., (2013), The effectiveness of industrial zones in the Czech Republic, Journal of Economics and Management.

Lambert et al., (2002), Eco-industrial parks: stimulating sustainable development in mixed industrial parks, Technovation 22, 471-484

Popescu et al, (2008), Eco-industrial Parks - an opportunity for the developing countries to Achieve Sustainable development, An Enterprise Odyssey, International Conference Proceedings, 239-247, University of Zagreb.

Tran Van Hau, (2011), Meet the needs of bank loans to enterprises in industrial parks and export processing zones, trade journals 12 .

Hoang Ngoc Hoa (2012), Industrial Parks and Export Processing Zones with Sustainable Development in Viet Nam - Current Status and Solutions, Economic and Development Journal 91.

Vu Dai Thang, (2012), Improving mechanisms and policies to develop industrial parks, export processing zones, economic zones, the Ministry of Planning and Investment.

Thanh Tung, Solutions for training human resources for industrial parks and export processing zones in Ho Chi Minh City, Journal of Labor and Social Affairs No. 248. 